\title{
The tribe Scrophularieae (Scrophulariaceae): A Review of Phylogenetic Studies
}

\author{
Mehrshid Riahi $^{1, *(1)}$ \& Farrokh Ghahremaninejad ${ }^{1}$ (i)
}

Key words: Phylogeny, Molecular phylogeny, Scrophularieae, Verbascum, Scrophularia.

Ključne besede: filogenija, molekularna filogenija Scrophularieae, Verbascum, Scrophularia.

Received: 26. 4. 2018

Revision received: 3. 1. 2019

Accepted: 1. 3. 2019

\begin{abstract}
Molecular data have been increasingly used to study the phylogenetic relationships among many taxa, including scrophs. Sometimes they have provided phylogenetic reconstructions that are in conflict with morphological data leading to a re-evaluation of long-standing evolutionary hypotheses. In this paper, we review reports of the recent knowledge of the phylogenetic relationships within Scrophularieae (2011-2017). The results of these analyses led to the following conclusions. (1) Species of Scrophularia have undergone one or more Miocene migration events occurred from eastern Asia to the North America with subsequent long dispersal and diversification in three main directions. (2) Allopolyploid and aneuploid hybrid speciation between Scrophularia species can occur, so hybridization and polyploidy have an important role for history of diversification. (3) The ancestral staminode type for the genus Scrophularia seems to be a large staminode. (4) Monophyly of the genus Verbascum with respect to the genus Scrophularia is strongly supported. (5) Oreosolen, is not monophyletic, because all accessions of Oreosolen were nested within Scrophularia. We discuss methods of data collection and analysis, and we describe the areas of conflict and agreement between molecular phylogenies.
\end{abstract}

\section{Izvleček}

Pri raziskavah filogenetskih odnosov med številnimi taksoni, vključno s črnobinovkami, so vse bolj pogoste tudi molekularne metode. V̌̌asih dobimo filogenetske rezultate, ki so v nasprotju z morfološkimi analizami, in zato so potrebni premisleki o dolgo veljavnih evolucijskih hipotezah. V članku predstavljamo pregled rezultatov raziskav filogenetskih razmerij v družini Scrophularieae med leti 2011 in 2016. Rezultati nam omogočajo naslednje zaključke: (1) vrste rodu Scrophularia v miocenu iz vzhodne Azije v Severno Ameriko migriralevsaj enkrat z nadaljnimi širitvami in diverzifikacijo v treh smereh. (2) med vrstami rodu Scrophularia se lahko pojavljata alopoliploidna in aneuploidna hibdridna speciacija, zato sta v zgodovini diverzifikacije hibridizacija in poliploidnost pomembni, (3) tip stamenoidija pri prednikih v rodu Scrophularia je bil velik, (4) rod Verbascum je v primerjavi z rodom Scrophularia monofiletski, (5) Oreosolen ni monofiletski, saj se celoten material rodu Oreosolen združuje v rod Scrophularia. Komentirali smo tudi zbiranje materiala in analize ter poudarili konflikte in strinjanje med molekuarnimi filogenijami. 


\section{Introduction}

Scrophularieae Dumort (= Verbasceae Dumort.) is one of the tribes of the family Scrophulariaceaes. str., which is a member of the lamiid clade (Olmstead et al. 2001, Angiosperm Phylogeny Group IV 2016). Besides Scrophularieae, Scrophulariaceae is composed of the tribes Aptosimeae, Buddlejeae, Hemimerideae, Leucophylleae, Limoselleae, Myoporeae, Scrophularieae and Teedieae (Oxelman et al. 2005, Angiosperm Phylogeny Group IV 2016). Although relationships among these groups are fairly well established, the relationships within tribes are conflicting based on the existing molecular phylogenies (Tank et al. 2006).

Species of Scrophularieae are perennial to annual herbs, with rosulate or elongate stem, cymose inflorescences, synthecousanthers, capitate to flattened or minutely bifid (Antherothamnus) stigma, septicidal capsule and pinnate to undivided leaves of various forms. Most of the Scrophulariaceae exhibit radial corolla symmetry; however Scrophularia is the most notable exception within this family with its two-lipped corolla (Kadereit 2004).

Monophyly of the traditional Scrophulariaceae, as defined by morphological characters is not supported by the works of Olmstead \& Reeves (1995) and Olmstead et al. (2001). Olmstead \& Reeves (1995) changed the circumscription of Scrophulariaceae and found two distinct clades named 'scroph I,' and 'scroph II'. Clade 'scroph I,' containing the type genus Scrophularia L. and several other genera e.g. Verbascum L. and was labelled Scrophulariaceae str. by Olmstead et al. (2001), while clade Scroph II is equivalent to the traditional Plantaginaceae. Further studies of molecular phylogenetic on the delimitation of the Scrophulariaceae (e.g., Oxelman et al. 1999, 2005, Rahmanzadeh et al. 2005, Albachet et al. 2005) have demonstrated the pattern recognized by Olmstead \& Reeves (1995) and Olmstead et al. (2001).

The Scrophularieae tribe, with more than 570 species (Fischer 2004, Mabberley 2008) is a large group that occurs throughout holarctic regions of the world (Hong 1983). Oxelman et al. (2005) based on molecular studies proposed a new classification for Scrophulariaceae that transferred Antherothamnus N. E. Br., Nathaliella B. Fedtsch., Oreosolen Hook. f., Rhabdotosperma (Murb.) Hartl, Scrophularia, and Verbascum into one tribe named Scrophularieae, although a robust synapomorphy for the tribe is not readily apparent. These taxa, unlike most other lineages in Scrophulariaceae, are predominantly distributed in the northern temperate zone: Antherothamnus (A. pearsonii), monotypic and native of Africa; Nathaliella (N. alaica) monotypic and restricted to Kyrgyzstan and western China, Oreosolen, a native of the northern Hima- laya and Tibet with one species, Rhabdotosperma with six species in tropical East Africa; Scrophularia with 270 extant species concentrated in Asia and Europe with only a few species in North America; Verbascum with 360 species in northern Africa, Europe and parts of Asia (Hassler 2017, Tank et al. 2006, Mabberley 2008) (Table 1).

This paper is a presentation of the recent knowledge of the phylogenetic relationships within Scrophularieae (2011-2017). Here, we have tried to discuss review and summarize the main conclusions from these studies in chronological order according to the first molecular study of the specific genus.

On the fact that Scrophularia and Verbascum with more than 630 species are the most frequent and abundant genera in the tribe Scrophularieae, these genera have been the subject of some phylogenetic studies and other small genera of this tribe have often been neglected by researchers in phylogenetic studies of Scrophularieae (Attar et al. 2011, Scheunert \& Heubl 2011, 2014, 2017, Ghahremaninejad et al. 2015, Sotoodeh 2015, Scheunert \& Heubl 2016, Valtueña et al. 2016, 2017). Here, we review and summarize the main conclusions from these studies.

\section{Morphological background}

Species of Scrophularia are annual, biennial or perennial to suffrutescent herbs or dwarf shrubs with ascending to erect stem. The inflorescence is a thyrse with cymose, often dichasial or monochasial partial inflorescences. The flowers are mostly zygomorphic and characterized by a 5-lobed calyx to middle, lobes equal. Corolla, distinctly 2-lipped corolla is lobes orbicular and typically a rudimentary fifth stamen of various shapes at the base of the upper lip. Stigma is capitate to weakly bilobed. The fruit is a capsule with septicidal - septifragous dehiscence (Kadereit 2004). The flowers of Scrophularia are characterized by a more or less equally 5-lobed calyx, and typically a rudimentary fifth stamen of various shapes at the base of the upper lip. The fruit is a capsule with septicidal - septifragous dehiscence (Fischer 2004).

Species of Scrophularia display high level of adaptive diversity due to changes in the habitats and ecological factors. Variability in Scrophularia might be expected to result of chromosomal evolution, through allopolyploidy (Carlbom 1969). Species of the genus Scrophularia rarely live in a hot desert environment but are found in coastal to alpine regions, where the majority of species occurred (Scheunert et al. 2014). Among the morphological traits like leaf venation, petal length, shape of the corolla tube, and life form which were used as distinguishing characters, leaf characters are the main distinguishing char- 
acteristics for Scrophularia species (Makbul et al. 2006, Scheunert et al. 2014).

The genus Verbascum is characterized by rosulate, biennial or perennial herbs with yellow-flowered, thyrsic or racemose inflorescences (Fischer 2004, Oxelman et al. 2005). Accessory flowers are found in various numbers and structures in the inflorescence of Verbascum.

The characters are commonly used to help distinguish Verbascum species are stamen numbers, stamen hair color, anther shape, capsule shape and size, number of flowers per node/bract and presence or absence of bracteole (Sotoodeh 2015). With the great variation in the flower features, especially size, shape and colour of the corolla, inflorescence length, and number of flowers make the identification of the species belonging to this genus exceedingly difficult. Hybrid between species is common in Verbascum and is commonly found where two or more species grow together, especially in disturbed habitats. Most characters of these hybrids were found to be intermediate between the putative parental species. Contribution of natural hybridization to the evolution of Verbascum has played an important role (e.g. Huber-Morath 1978).

Verbascum exhibit nearly radial corolla symmetry. Because of its nearly radially symmetric flowers, alternate phyllotaxis, and presence of a fifth stamen, most botanists think of Verbascum as an oddball for the family and considered it to be a transitional genus between the Solanaceae and Scrophulariaceae. However, most of the Scrophulariaceae, as we now define them, exhibit radial corolla symmetry, so it is Scrophularia, with its bilabiate corolla that is the real oddball (Olmstead 2002).

Verbascum resembles Veronica in some flora traits, including actinomorphic flowers (Sharifnia 2007). However, the artificial nature of this similarity has been demonstrated by the results of molecular phylogenetic studies and it was placed in the separate family Plantaginaceae (Olmstead et al. 2001, Albach \& Chase 2004, Oxelman et al. 2005, Tank et al. 2006).

\section{Taxonomic history and classification of Scophularia}

The genus Scrophularia L. includes about 270 extant species, distributed mainly in the holarctic region of the Old and New World (Ortega Olivencia 2009).

The first attempt to establish infrageneric relationships within Scrophularia was carried out by Wydler (1828) who proposed two main sections and these sections were named by G Don (1838) as Scrophularia sects. Venilia G.
Don and Scorodonia G. Don (= S. sect. Scrophularia) and complemented by a third, Canina G. Don.

Don (1838) placed Scrophularia in tribe Scrophularieae, while Bentham, after first associating it with Verbascum L. in Verbasceae (Bentham 1835), later transferred it into Cheloneae of Antirrhinoideae (Bentham 1846, 1876).

Bentham (1846) classified the genus into three sections: sect. Venilia, sect. Scorodonia, and sect. Tomiophyllum. The genus Scrophularia was further separated into three section: sect. Ceramathe, sect. Pycnanthium, and sect. Minima by Boissier (1879), who accepted the two sections, sect. Scorodonia and sect. Tomiophyllum, proposed by Bentham.

In the only world-wide and comprehensive revision of the genus Scrophularia, Stiefelhagen (1910) recognized two sections and five subsections. Stiefelhagen (1910) characterized sect. Tomiophyllum Benth. as having species without anastomosing leaf venation and sect. Anastomosantes Stiefel. with anastomosing venation on the dorsal surface (Table 2). Stiefelhagen (1910) suggested that $S$. nodosa L. was one of the ancestral parents of the North American polyploid species. Indeed, the New World Scrophularia and the Old World $S$. nodosa show very similar morphological features (Carlbom 1968). However, this assumption was rejected by Pennell $(1935,1947)$. Stiefelhagen approach (1910) to generic circumscription largely followed Ortega Olivencia and Devesa Alcaraz (1993)'s proposal in recognizing to sections; sect. Anastomosantes and sect. Canina G. Don in a revision of the genus for the Iberian Peninsula.

Regional taxonomic work on the genus has been accomplished for Russia (Shishkin in Komarov1955), western North American (Shaw 1962) Europe (Tutinet al. 1968), Turkey and the East Aegean Island (Lall \& Mill 1978), and the Iranian Plateau (Grau 1981). These authors did not accept the former infrageneric classification and defined a new subgeneric classification; for example, Lall \& Mill (1978) based on the division of the lamina proposed two informal groups in the genus, and Grau (1981b) designated 23 greges for the Iranian Plateau species of Scrophularia. Only Shishkin in Komarov (1955) accepted the general outline of Stiefelhagen's (1910) infrageneric classification with a few modifications.

\section{Taxonomic history and classification of Verbascum}

The genus Verbascum includes -360 species, distributed throughout the northern hemisphere. The taxonomy of Verbascum has been the subject of controversial debate 
and differs from treatment to treatment. Initially, taxa recognized today as Verbascum were discussed primarily in terms of alternative generic placements and circumscriptions (Karavelioğullari \& Aytaç 2008).

The genus was named Arcturus by Belli in 1601, as synonym of Blattaria by Morison in 1715. The original circumscription of Verbascum dates from Linnaeus (1753), who described specimens with 4 stamens as Celsia L. and specimens with 5 stamens as Verbascum. Due to oblongcylindrical capsule, Fischer and Meyer (1843) segregated $V$. natolicum as the new genus Staurophragma. Some taxa which belong to the genus Celsia were considered as Allonsona (Ruiz \& Pav. 1786) Scrophularia by Wydler in 1828, Thapsandra by Griseb. in 1844, Janthe by Griseb. in 1844, Triguera by Dunal in 1852, Alectra by Schintz in 1889. Linneaus's concept for Celsia and Verbascum, based on the presence of 5 stamens, has been adopted in Bentham's treatment (1846). Kuntze (1891) merged the genus Celsia in Verbascum based on overall similarity. But Murbeck (1925) separated Celsia and Verbascum based on number of stamens, sessile or stipitate placenta, and number of flowers within each bract. Some authors observed that the presence of four or five stamens is not always consistent and prefer to transfer Celsia and Staurophragma to Verbascum (Ferguson 1972, Huber-Morath 1978, Karavelioğullari 2008). This was later confirmed by the results of molecular phylogenetic studies (Ghahremaninejad et al. 2015).

The systematics of Verbascum has received only limited attention in recent studies of Scrophulariaceae, so it is one of the least understood regarding infrageneric classification (Dahlgren 1989). The most comprehensive systematic treatment of Verbascum is that of the Swedish botanist Svante Murbeck (1933) who published two monographs on Verbascum and Celsia and a series of two additional, supplementary and interpretative studies on the genus (Murbeck 1925, 1933, 1936, 1939). Murbeck (1933) divided the genus Verbascum into two sections based on seed morphology, Aulacospermae Murb. with a longitudinal corrugated seeds, and Bothrospermae (Murb.) Kamelin with transversely corrugated and alveolate seeds. In section Bothrospermae, there are two sub-sections based on having a single or several flower within each bract.

An alternative classification system of Verbascum was proposed by Huber-Morath (1978) in his revision of the Turkish members of the genus. Huber-Morath (1978) in his treatment of the genus established 13 artificial groups A to $M$ among 243 Verbascum specieswith129 additional hybrids and argued that all Turkish species of Verbascum were falling within sect. Bothrospermae Murb. (HuberMorath 1971, 1978). These informal groups are characterized by reproductive character states such as morpholo- gy of androecium, number of flowers in axil, and presence of bracteole.

Regional studies were published for the U.S.S. R. (Fedchenko 1955) and Iran plateau (Huber-Morath 1981). Fedchenko (1955), in the Flora of the U. S. S. R., segregated Verbascum and Celsia as separate genera and recognized 51 species of the genus Verbascum. In Europe Ferguson (1972) recognized almost a hundred species of Verbascum, including Celsia. Huber-Morath (1981), in his treatment of the species from Iran plateau, included the genus Celsia in the genus Verbascum, did not propose any infrageneric classification for the 49 species and additional 4 hybrids included.

The taxonomical position of the genus Verbascum is controversial (Bentham 1846, Pennell 1935, Yilmaz \& Dane 2012). The genus Verbascum is considered to be the representative genus of the subfamily Verbascoideae, previously Pseudosolanoideae and tribe Verbaceae by Bentham, with nomenclature based on analogies with the family Solanaceae (Juan et al. 1997). Verbascum was considered to be a transitional genus between the Solanaceae and Scrophulariaceae because of its nearly regular floral symmetry, alternate phyllotaxis, and presence of a fifth stamen. Recently, Oxelman et al. (2005) re-assessed the classification of Scrophulariaceae based on phylogenetic studies and pointed out a sister group relationship between Verbascum and Scrophularia, therefore transferred these genera to tribe Scrophularieae and changed their position.

\section{Type of molecular data}

During seven years of molecular phylogenetic analyses of Scrophularieae taxa, from the beginning of 2011 to the end of 2017, 12 studies have been published, which cover three genera of the tribe Scrophularieae and address question at generic level (Scheunert \& Heubl 2011, 2014, 2017, Attar et al. 2011, Navarro-Pérez et al. 2013, Ghahremaninejad et al. 2015, Rodríguez-Riaño et al. 2015, Sotoodeh 2015, Valtueña et al. 2016, 2017, Chen et al. 2017). All studies have used only sequence data as the marker in assessing phylogenetic relationships in the Scrophularieae. Sequence comparisons of the nuclear ribosomal internal transcribed spacer (ITS) andtrnQrps16and psbA-trnH as cpDNA genes, have been used widely in phylogenetic studies of the tribe Scrophularieae.

Totally, 10 different sequence markers have been applied, two nuclear DNA (ITS, ETS) and eight from cpDNA (matK, ndhF, $p s b A-t r n H, p s b J-p e t A$, trnQ-rps16, trnL$F$, trnS-G, $\operatorname{trn} Y-T$ ) (Table 3). More than 2100 sequences were available from GenBank/National Center for Bio- 
technology Information (NCBI) at the end of 2017 from the tribe Scrophularieae. Each single genetic marker has its own properties and influence on the analysis and interpretation, which will be briefly described below.

Sequence comparison of the ITS region is widely used in taxonomy and molecular phylogeny because of possessing a high degree of variation even between closely related species and rapid concerted evolution (Baldwin et al. 1992). When compared with other single copy protein coding genes, nuclear rRNA genes are routinely amplified due to their small size associated to the availability of highly conserved flanking sequences and easy to detect even from small quantities of DNA because of the high copy number of the rRNA clusters. Based on these technical advantages, ribosomal genes are among the first sequences that have been extensively exploited in phylogenetic analyses of the tribe Scrophularieae (Scheunert \& Heubl 2011, 2014, 2017, Attar et al. 2011, Navarro-Pérez et al. 2013, Ghahremaninejad et al. 2015, RodríguezRiaño et al. 2015, Sotoodeh 2015, Valtueña et al. 2016, 2017, Chen et al. 2017).

It should be admitted, however, that the use of ITS sequence information can possibly mislead phylogenetic inference by the frequent occurrence of multiple copies of ITS, the effects of concerted evolution, its complex and unpredictable evolutionary behavior which reduce its utility for phylogenetic analysis, so it is suggested to clone this marker in such cases in order to obtain much more reliable data (Álvarez \& Wendel 2003).

The second most commonly used marker regions in phylogenetic relationships within tribe Scrophularieae are non-coding regions in the large single-copy region of the chloroplast genome, include the $\operatorname{trn} Q-r p s 16, p s b A-\operatorname{trn} H$, $\operatorname{trn} L-F, \operatorname{trn} S-G$, and $\operatorname{trn} Y-T$ intergenic spacers as well as the matK and ndhF (coding for maturase involved in RNA splicing and subunit F of NADP dehydrogenase, respectively).

At present, many plant phylogenetic studies are based on the use of chloroplast gene sequences. In plants, chloroplast DNA (cpDNA) is smallest as compared to mitochondria and nuclear genome. Several features, foremost its conservative mode of evolution in terms of nucleotide substitution with very little rearrangements, make cpDNA an extremely valuable molecule for resolving phylogenetic relationships especially at deep levels of evolution (Dong et al. 2012). However, selection of a gene of sufficient length and appropriate substitution rate is a crucial step.

About 320 species in three genera of Scrophularieae have been surveyed for two or more markers. Of these, over 320 species have been studied for ITS, 336for the $\operatorname{trnL}-F$ spacer, 221 for $\operatorname{trn} Q-r p s 16,77$ for matK, 116 for
ndhF, 147 for $p s b A$-trnHspacer, 120 for $\operatorname{trn} S-G$ spacer about 42 for the $\operatorname{trn} Y-T$ spacer, one for $p s b J-p e t A$. in this paper, we will discuss the phylogenetic relationships of the Scrophularia, Verbascum, and Oreosolen respectively.

\section{Molecular systematics of Scrophularia}

Phylogenetic and biogeographic relationships of the New World species of Scrophularia was estimated by Scheunert and Heubl(2011), who used ITS, $\operatorname{trn} Q-r p s 16$, and $p s b A-$ trnH spacer of 26 species of the genus and three outgroups.

Scheunert \& Heubl (2011) analyzed a set of Scrophularia species, including North America and the Greater Antilles species (all except three species of the genus), together with representatives of eastern Asia species, to test if the New World species of Scrophularia were monophyletic and to ascertain geographical origin and dispersal sequence.

Their nuclear and combined cp markers analyses gave similar results except for the placement of some species, a finding that shows that the origin of some Scrophularia species in North America (S. lanceolata Pursh.) was effected by a hybridization event.

Scheunert \& Heubl (2011) proposed an eastern Asian origin at the Oligocene-Miocene boundary (24.16 mya) for the New World taxa of Scrophularia. It was also shown that one or more Miocene migration events occurred from eastern Asia to the North America via the Bering Land Bridge with subsequent long dispersal and diversification in three main directions. In their analysis Japanese taxa formed a grade to the New World taxa of Scrophularia which indicate an intercontinental disjunction. Scheunert \& Heubl (2011) identified three subclades corresponding to biogeography patterns of the genus in the New World. Furthermore, their data rejected the view that all New World species were conspecific with $S$. nodosa as proposed by Stiefelhagen (1910).

In a study investigating phylogenetic relationships of Scrophularia in Euroasia, Attar et al. (2011) analyzed 20 taxa for ITS and $\operatorname{trn} S-G$. The results suggested that the clade of $S$. umbrosa was the earliest diverging species within the genus. Their phylogenetic analysis did not support informal species groups recognized by Grau (1981).

This study addressed hypotheses about evolution of major morphological characters. They optimized those characters on a phylogenetic tree and shown that leaf arrangement and morphology have evolved several times but foliate inflorescence agreed with the phylogeny. 
Navarro-Pérezet et al. (2013) investigated the phylogeny and biogeography of the Scrophularia to reconstruct the ancestral pattern of pollination system. They used a detailed molecular analysis (ndhF, trnL-F and ITS) from 116 taxa of Scrophularia covering all recognized sections and subsections. All maximum parsimony, maximum likelihood and Bayesian inference analysis gave highly congruent results.

They also performed relaxed molecular clock analyses of three molecular data sets, in order to infer divergence times among Scrophularia lineages. They confirmed that Scrophularia diverged in the late Miocene and found the sect. Caninae as a mostly monophyletic group that is embedded within sect. Scrophularia. They concluded that the semi-shrub species of sect. Caninae descended from herbaceous species and diverged in the Pliocene (or late Miocene).

It was inferred that the four focal species (the western Mediterranean S. sambucifolia and S. grandiflora, the Tyrrhenian S. trifoliate and the Canarian S. calliantha) originated between the late Pliocene and the Pleistocene. According to the analyses, a strong geographic rather than floral phenotypic pattern was obtained.

It has been proposed that wasp pollination was the ancestral pollination system not only for the Old World lineages but also for the American lineage. There have been multiple shifts from wasp pollination to hoverfly, mixed vertebrate-insect and bird pollination within the genus. They also concluded that bird pollination showing its origin in the Pliocene-Pleistocene have been very successful in the genus due to reconstructions rejecting potential reversals from bird to wasp pollination syndromes.

Navarro-Pérez et al. (2013) found that $S$. lowei is sister to $S$. arguta and the two species diverged from each other about the Pliocene-mid Pleistocene (0.43-5.5 Ma); suggested a peripatric speciation of the Madeiran $S$. lowei from its ancestor $S$. arguta.

The genus was later reinvestigated by Scheunert \& Heubl (2014), who used trnQ-rps16, ITS, and combined data in order to understand the biogeographic pattern and phylogenetic relationships of the genus in the Western Mediterranean and Macaronesia region. The analyses were based on a set of 65 individuals representing 45 taxa of Scrophularia and Bayesian inference, maximum likelihood and statistical parsimony networking were used. They found significant incongruences between the cpDNA and nrDNA datasets, and the conclusion was that the substantial incongruence observed among markers was a result of high frequent hybridization in the Western Mediterranean Scrophularia taxa. Of the investigated taxa S. sublyrata, S. reuteri, S. oxyrhyncha, S. valdesii and $S$. viciosoi have originated through homoploid hybrid spe- ciation. This study suggests that allopolyploid (S. alpestris) and aneuploid (S. viciosoi) hybrid speciation between Scrophularia species can occur. It was also suggested that a $S$. canina - like $(2 \mathrm{n}=30)$ and a $S$. umbrosa - like $(2 \mathrm{n}$ = 26) ancestors produced offspring for the Macaronesian and Iberian clade. The chromosome number was doubled subsequently to $2 \mathrm{n}=56$ during the Scrophularia allopolyploid event and then increased further by aneuploidy $(2 \mathrm{n}$ $=58$ ) in the Macaronesian and Iberian clade. They found strong evidence for the occurrence of reticulate evolution in the genus and that the mechanisms evolved to maintain a high level of Scrophularia species diversity in the Western Mediterranean and Macaronesia.

The studies discussed above supported a clear association between hybridization and topographical complexity in the Iberian Peninsula lineage. Their phylogenetic analysis indicated Macaronesian taxa as monophyletic and distinctly divided into three subclades. Based on the molecular phylogeny, they concluded that multiple origins of Scrophularia occurred in Macaronesia and the colonization of Macaronesia by Scrophularia involved at least four different events. This study supported that $S$. lowei is sister to $S$. arguta and agreed with earlier results (Navarro-Pérez et al. 2013).

Evolution of the staminode was investigated in three species of Scrophularia by Rodríguez-Riaño et al. (2015). They optimized all four staminode types on a phylogenetic tree from datasets of reported studies and showed that the ancestral staminode type for the genus seems to be a large staminode. The staminode seems to have completely disappeared at least twice; once in S. crithmifolia, which is included into sect. Caninae, and another in a pool of species belonging to sect. Anastomosanthes subsect. Vernales (S. vernalis, S. lunariifolia, S. chrysantha, S. orientalis, and S. pauciflora).

According to their optimization on the tree, staminods is present in some derived species. It was also suggested that the petaloid portion of the large staminodes acted as a barrier to reduce nectar dilution by rainwater. However, due to the existence of several polytomies at the base of the tree, some of their phylogenetic results should be considered with more caution.

From the Canary Islands and Morocco, Valtueña et al. (2016) used the phylogenies of the Scrophularia arguta in a biogeographic study. Thirty-three populations of the species were analyzed for the nuclear ITS and ETS and the chloroplast markers $p s b A-t r n \mathrm{H}$ and psbJ-petA. The data were analyzed in combination and separately based on maximum likelihood and Bayesian evolutionary methods.

Based on the investigated taxa, S. arguta occupy a basal phylogenetic position in the genus. The Bayesian stochas- 
tic search variable selection analyses (BSSVS) also supported a middle-late Miocene (7.5-13.7 Ma) origin for $S$. arguta and agreed with earlier results (Navarro-Pérez et al. 2013). Valtueña et al. (2016) show that most divergence events of $S$. arguta occurred in the Pliocene (1.38-5.43 Ma).

In their study of the $S$. arguta, Valtueña et al. (2016) suggested at least three different events of Canary Islands colonization, including two ancestral patterns of colonization and dispersal probably happened in the Pliocene and that the Gran Canaria species descended from mainland instead from the closest islands where the recent third event of colonization has occurred.

Based on the molecular phylogeny, Valtueña et al. (2016) concluded that the high level of genetic variation among Canarian $S$. arguta populations indicates a rapid pattern of speciation and colonization in a eastwesterly direction from southwest Europe to northwest Africa coinciding with the aridification of northern Africa and the formation of the Mediterranean climate.

Scheunert \& Heubl (2017) in another article about the reticulate evolutionary history of Scrophularia analyzed the genus with a denser sampling of 147 species. They analyzed and compared the utility of the nuclear ITS region with the cpDNAtrn Q-rps16and $\operatorname{trn} \mathrm{L}-\operatorname{trn} \mathrm{F}$ for the genus Scrophularia.

Their molecular data did not support Oreosolen as monophyletic due to the deeply nested position of this genus with in Scrophularia. Only Sect. Tomiophyllum was supported as monophyletic entity which is derived from the Sect. Anastomosantes.

They used the ad hoc 2ISP-informative maximum likelihood approach and Additive Polymorphic Sites for coding of chloroplast indels and ITS intra-individual site polymorphisms. They also performed Bayesian and likelihood analysis of five molecular data sets, one of combined plastid markers and coded indels, one of uncoded ITS, one of coded ITS following the 2ISP-informative approach, one of coded ITS based on Additive Polymorphic Sites and one of coded ITS following the 2ISP-informative approach including cloned sequences. Scheunert \& Heubl (2017) found high intra-individual polymorphism of the ITS region in the five species $(S$. auriculata L., S. lyrata Willd., S. argute, S. nodosa L., S. olympica Boiss.). They concluded that since there were a large number of polymorphisms in the ITS region, understanding of the formation mechanisms of these polymorphisms was difficult.

Scheunert \& Heubl (2017) explored the potential utility of the ITS polymorphism in a phylogenetic analysis by using 2ISP coding and the ad hoc implementation in maximum likelihood. They found that the polymorphism does not transcend species boundaries in this group and improves the resolution of the phylogenetic tree so could be used in a phylogenetic analysis without contradicting the phylogenetic signal.

Neighbor-Net and consensus network methods were applied for examination of within-dataset uncertainty as well as among-dataset incongruence. There was considerable incongruence among nuclear and plastid phylogenies. They suggested that these discrepancies could be the result of incomplete lineage sorting and reticulation, which is possibly consistent with inter-array heterogeneity and pseudogenization in ITS in the presence of incomplete concerted evolution.

Based on the molecular phylogeny, Scheunert \& Heubl (2017) concluded that Scrophularia has a Southwestern Asian origin where the major radiation has occurred during the Miocene and that migrated in various directions.

They proposed that Scrophularia migrated to China approximately six mya. They further suggested that the disjunct distribution of the genus in western North America and the western part of eastern Asia is a result of longdistance dispersal. In North America, Scrophularia has colonized dup to three times. They also proposed Westward migration events from the ancestral region to the Mediterranean, Northern Africa, and Europe.

The studies discussed above provide strong support that within the genus Scrophularia, hybridization and polyploidy had an important role for history of diversification. The presence of incomplete lineage sorting and hybridization means that retrieving species trees in such group of species is going to be hard.

Species Scrophularia lowei was investigated by Valtueña et al. (2017), who used the ITS, ETS, $p s b \mathrm{~A}-t r n \mathrm{H}$ and $p s-$ bJ-petA of five populations of the species from Macaronesia to determine the phylogenetic origin of $S$. lowei with a focus on relationships between $S$. lowei and $S$. arguta.

The nuclear and plastid analysis did not give similar results. Result of nuclear analyses show that $S$. lowei is monophyletic and sister to $S$. arguta but based on plastid analysis these two taxa constitute a well-supported clade. S. lowei and S. arguta exhibit high degrees of phenotypic and geographic differentiation but in this study only high genetic differentiation at nuclear loci among these species was found.

The result confirmed those based on ndhF, $\operatorname{trn} L-F$ and ITS data (Navarro-Pérez et al. 2013) for the recent peripatric speciation of $S$. lowei from $S$. arguta, but more taxa were included. This is in contrast to the Scheunert \& Heubl (2014) which they suggested that these species are independent sister lineages.

Due to low variation in the plastid markers between S. lowei and western Canarian populations of S. arguta, Valtueña et al. (2017) hypothesized that these two groups 
of populations have recently diverged from a common ancestor. The biogeographic implication was that distribution range of $S$. lowei is a result of short-distance dispersal from Canary Islands into Madeira.

\section{Molecular systematics of Verbascum}

A first attempt to reconstruct the Verbascum phylogeny based on molecular data was published in 2015 by Ghahremaninejad et al. (2015) The data were from nrDNA ITS and three noncoding cpDNA markers (trnS-G, $p s b \mathrm{~A}-\operatorname{trn} \mathrm{H}$ and $\operatorname{trn} Y-T)$. Included were 421 informative characters for forty-one taxa representing two different genera. Three outgroup genera from the tribes Veroniceae, Antirrhineae and Digitalideae (Plantaginaceae) were chosen in this study. It was shown that there is strong support for monophyly of the genus Verbascum with respect to the genus Scrophularia by molecular data in agreement with morphological studies of Scrophularieae (Kuntze1891, Huber-Morath 1978, Murbeck 1933). Ghahremaninejad et al. (2015) found no support for the current subgeneric classification of Verbascum (Murbeck 1933). Ghahremaninejad et al. (2015) demonstrated that all morphological characters (stamen number, glandular or stellate hairs, fasciculate or solitary flowers, bracteoles, corolla color)traditionally used to classify the genus suggested by Murbeck (1933) and Huber-Morath (1981) are not helpful in shaping a classification for Verbascum as these features was very homoplastic within the genus.

Celsia has been recognized by taxonomist for more than two centuries that was diagnosed only by having 4 stamens from Verbascum (Linnaus1753, Bentham 1846, Murbeck 1925). Ghahremaninejad et al. (2015) also provide strong support for the synonymizations of Celsia into Verbascum and confirmed the hypothesis of Ferguson (1972) and Huber-Morath (1978, 1981).

The genus Verbascum was one of the two genera studied by Sotoodeh (2015). Earlier molecular analysis (Ghahremaninejad et al. 2015) had indicated that the genus could be monophyletic, and Sotoodeh (2015) further investigated the genus in Iran and his result was very much in agreement with Ghahremaninejad et al. (2015).

Sotoodeh (2015) analyzed a combined data set(the ITS, matK, $p s b A-t r n H, t r n S-G$ and $t r n L-F$ sequences) for seventy -seven Iranian taxa in thirty-six species of which sixteen species were shared with Ghahremaninejad et al. (2015).

That analysis resulted in a tree with two supported clades, but relationships among taxa and the taxonomy within the clades have remained largely unclear. The results confirmed thosebased on $\operatorname{trn} S-G, p s b \mathrm{~A}-\operatorname{trn} \mathrm{H}$ and trnY-T data (Ghahremaninejad et al. 2015) for Celsia as a synonym of Verbascum, but more taxa were included. Sotoodeh (2015) found a combination of morphological characters may be helpful for grouping.

\section{Molecular systematics of Oreosolen}

The genus Oreosolen, monotypic and restricted to the Himalaya and Qinghai-Tibetan Plateau, was analyzed with one nuclear (ITS) and three chloroplast markers $(t r n L-F, p s b \mathrm{~A}-\operatorname{trn} \mathrm{H}$, and $\operatorname{trn} \mathrm{Q}-r p s 16)$ by Chen et al. (2017). They included 104 taxa of only two genera, Oreosolen and Scrophularia (mainly sequences from GenBank).

Chen et al. (2017) showed that the genus is not monophyletic in accordance with the earlier study (Oxelman et al. 2005, Scheunert \& Heubl 2017). The analysis clearly demonstrated that all accessions of Oreosolen (except one accession) were nested within Scrophularia and formed a sister to an East Asian clade of Scrophularia. Chen et al. (2017) transferred Oreosolen to Scrophularia and a new combination (Scrophularia wattii (Hook. f.) P. Li) was proposed based on their sequence data.

\section{Conclusions}

From the twelve molecular studies of the tribe reviewed in this article, we now have a good phylogenetic framework of the tribe. It is obvious from this survey that all studies so far have focused on the generic level with an emphasis on the delimitation of species. However, no phylogenetic studies have been performed on the establishment of a tribe-wide phylogeny. To have a detailed phylogenetic picture of the tribe and to understand circumscriptions of genera, we need sequence data representing all described genera.

We still do not know how the genera Nathaliella, and Rhabdotosperma are related to the other genera in this tribe. Oxelman et al. (2005) based on phylogenetic analysis of three molecular markers found that Antherothamnus to be sister to a clade including Scrophularia, Oreosolen and Verbascum, but no morphological evidence supported this affinity (Figure 1). So the groups that would be most affected are the monotypic and oligotypic genera, such as Antherothamnus, Nathaliella, and Rhabdotosperma need critical studies to establish their monophyly. On the other hand phylogenetic studies of Ver- 
bascum have suffered from low taxon sampling and were usually limited to regional works (Ghahremaninejad et al. 2015, Sotoodeh 2015). It seems that our information is insufficient to reconstruct well-supported subgeneric groups and pattern of speciation and distribution in this large genus.

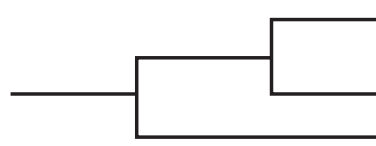

\section{Scropularia \& Nathaliella}

\section{Verbascum Antherothamnus}

Figure 1: Phylogenetic relationships among genera of the Scrophularieae (modified from Oxelman et al. (2005) and Scheunert \& Heubl (2017)).

Slika 1: Filogenetski odnosi med rodovi Scrophularieae (po Oxelman et al. (2005) in Scheunert \& Heubl (2017)).

\section{Acknowledgements}

This work has been supported by grants from the Research and Technology Vice-Chancellor of the Kharazmi University (Project NO. 4-179624) to Mehrshid Riahi. Thanks are given to the reviewers for their instructive comments and suggestions. The authors would like to thank Dr. John Edmondson (Kew Botanical Garden, UK) for language editing on manuscript.

Mehrshid Riahih (D), https://orcid.org/0000-0002-1197-8413 Farrokh Ghahremaninejad (D, https://orcid.org/0000-00015860-9976

\section{References}

Albach, D. C. \& Chase, M. W. 2004: Incongruence in Veroniceae (Plantaginaceae): evidence from two plastid and a nuclear ribosomal DNA region. Molecular Phylogenetics and Evolution 32: 183-197.

Albach, D., Meudt, H. \& Oxelman. B. 2005: Piecing together the "new" Plantaginaceae. American Journal of Botany 92: 297-315.

Álvarez, I. \&Wendel, J. F. 2003: Ribosomal ITS sequences and plant phylogenetic inference. Molecular Phylogenetics and Evolution 29: 417-434.

Attar, F., Riahi, M., Daemi, F. \& Aghabeigi, F. 2011: Preliminary molecular phylogeny of Eurasian Scrophularia (Scrophulariaceae) based on DNA sequence data from trn S-trn G and ITS regions. Plant Biosystems 145: 857-865.

Baldwin, B. G. 1992: Phylogenetic utility of the internal transcribed spacers of nuclear ribosomal DNA in plants: an example from the Compositae. Molecular Phylogenetics and Evolution 1:3-16.

Bentham, G. 1846: Scrophulariaceae. In: de Candolle, A. (ed): Prodromus Systematis Naturalis Regni Vegetabilis: Masson: Paris. $186-586$
Boissier, P. E. 1879: Flora orientalis. vol. 4, part 2. Geneva, H. Georg.

Calbom, C. 1969: Evolutionary relationships in the genus Scrophularia L. Hereditas 61: 287-301.

Chen, C., Cai, M. Q., Xu, B, Jin, X. J., Wang, R. H., Li, P., Zhao, Y. P., \& Fu, C. X. 2017: Systematic position of Oreosolen (tribe Scrophularieae, Scrophulariaceae) based on nuclear and plastid sequences. Journal of Systematics and Evolution 999: 1-7.

Dahlgren, G. 1989: The last Dahlgrenogram. System of classification of the dicotyledons. In: Tan, K. (ed.): The Davis and Hedge Festschrift: plant taxonomy, phytogeography and related subjects. Edinburgh, Edinburgh University Press.

Dong, W., Liu, J., Yu, J., Wang, L. \& Zhou, S. 2012: Highly variable chloroplast markers for evaluating plant phylogeny at low taxonomic levels and for DNA barcoding. PLoS One 7 (4), e35071.

Fedchenko, B. A. 1955: Verbascum L. In: Shishkin, B. K. S. \& Bobrow, E. G. (eds.): Flora U. S. S. R. Izdatel'stvo Akademii Nauk S.S.S.R., Leningrad 22: 132-197.

Ferguson, I. K. 1972: Verbascum L. In: Heywood, V. H., Tutin, G. T., Burges, N. A. et al. (eds.): Flora Europaea vol. $3: 205-216$. Cambridge, Cambridge University Press.

Fischer, E. 2004: Scrophulariaceae. Flowering Plants Dicotyledons, 333-432, Springer, Berlin, Heidelberg.

Ghahremaninejad, F., Riahi, M., Babaei, M., Attar, F., Behçet, L. \& Sonboli, A. 2015: Monophyly of Verbascum (Scrophularieae: Scrophulariaceae): evidence from nuclear and plastid phylogenetic analyses. Australian Journal of Botany 62: 638-646.

Grau, J. 1981: Scrophularia. In: Rechinger, K. H. (ed.): Flora Iranica. vol 147: 213-284. Graz, Austria: Akademische Druck- u. Verlagsanstatt.

Hassler, M. 2017: World plants: Synonymic checklists of the vascular plants of the world. In: Roskov, Y., Abucay, L., Orrell, T., Nicolson, D., Bailly, N., Kirk, P., Bourgoin, T., van Nieukerken, E. (eds.): Species 2000 \& ITIS Catalogue of Life Available from www.catalogueoflife. org/col [accessed 11 January 2017]

Huber-Morath, A. 1978: Verbascum. In: Davis P. H. (ed.): Flora of Turkey and The East Aegean Islands. vol 6: 461-603. Edinburgh University Press, Edinburgh

Huber-Morath, A. 1981: Verbascum. In: Rechinger K. H. (ed): Flora Iranica vol: 147: 5-51. Graz. Austria: Akademische Druck- u. Verlagsanstatt.

Juan, R., Fernandez, I. \& Pastor, J. 1997: Systematic consideration of microcharacters of fruits and seeds in the genus Verbascum (Scrophulariaceae) Annals of Botany 80: 591-598.

Kadereit, J. W. 2012: Flowering Plants: Dicotyledons: Lamiales (except Acanthaceae Including Avicenniaceae. vol. 7, Springer.

Karavelioğullari, F. \& Aytaç, Z. 2008: Revision of the genus Verbascum L.(Group A) in Turkey. Journal of the Botanical Research Institute of Texas 1: 9-32.

Kuntze, C. 1891: Orchidaceae. Revisio generum plantarum 2: 645-682.

Lall, S. \& Mill, R. 1978: Scrophularia. In: Davis, P. H. (ed.): Flora of Turkey and The East Aegean Islands. Vol 6: 603-647. Edinburgh University Press, Edinburgh. 
Linnaeus, C. 1753: Species plantarum. vol. 2. Stockholm.

Mabberley, D. J. 2008: Mabberley's plant-book: a portable dictionary of plants, their classifications and uses. Cambridge University Press, Cambridge.

Makbul, S., Coskuncelebi, K., Türkmen, Z. \& Beyazoglu, O. 2006: Morphology and anatomy of Scrophularia L.(Scrophulariaceae) taxa from NE Anatolia. Acta Biologica Cracoviensia Series Botanica 48: $33-43$.

Murbeck, S. 1925: Monographie Der Gattung Celsia. Hakan Ohlssons Buchdruckerei, Lund.

Murbeck, S. 1933: Monographie der Gattung Verbascum. Hakan Ohlssons Buchdruckerei, Lund.

Murbeck, S. 1936: Nachträgezur Monographie der Gattung Verbascum. CWK Gleerup, Lund.

Murbeck, S. 1939: Weitere Studienüber die Gattungen Verbascum und Celsia. CWK Gleerup, Lund.

Navarro-Pérez, M. L., López, J., Fernández-Mazuecos, M., RodríguezRiaño, T., Vargas, P. \& Ortega-Olivencia, A. 2013: The role of birds and insects in pollination shifts of Scrophularia (Scrophulariaceae). Molecular Phylogenetics and Evolution 69: 239-254.

Olmstead, R. G. \& Reeves, P. A. 1995: Evidence for the polyphyly of the Scrophulariaceae based on chloroplast $\mathrm{rbcL}$ and $\mathrm{ndhF}$ sequences. Annals of the Missouri Botanical Garden 82 (2): 176-193.

Olmstead, R. G. 2002: Whatever happened to the Scrophulariaceae. Fremontia 30: 13-22.

Olmstead, R. G., Wolfe, A. D., Young, N. D., Elisons, W. J. \& Reeves, P. A. 2001: Disintegration of the Scrophulariaceae. American Journal of Botany 88: 348-361.

Ortega-Olivencia, A. \& Devesa, A. J. 1993: Revisión del género Scrophularia L. (Scrophulariaceae) en la peninsula Ibérica e Islas Baleares, Ruizia, Monografías del Real Jardín Botánico, 11, 160 p.

Ortega-Olivencia, A. \& Devesa, J. 2009: Scrophularia L. In: Flora Iberica. 13: 97-134. CSIC, Madrid.

Oxelman, B., Backlund, M. \& Bremer, B. 1999: Relationships of the Buddlejaceae s. 1. Investigated using parsimony jackknife and branch support analysis of chloroplast $\mathrm{ndhF}$ and $\mathrm{rbcL}$ sequence data. Systematic Botany 24 (2): 164-182.

Oxelman, B., Kornhall, P., Olmstead, R. G. \& Bremer, B. 2005: Further disintegration of Scrophulariaceae. Taxon 54: 411-425.

Pennell, F. W. 1947: Some hitherto undescribed Scrophulariaceae of the Pacific states. Proceedings of the Academy of Natural Sciences of Philadelphia 99: 155-199.

Pennell, F. W. 1935: The Scrophulariaceae of eastern temperate North America. Academy of Natural Sciences, Philadelphia.

Rahmanzadeh, R., Müller, K., Fischer, E., Bartels, D. \& Borsch, T. 2005: The Linderniaceae and Gratiolaceae are further lineages distinct from the Scrophulariaceae (Lamiales). Plant Biology 7: 67-78.

Rodríguez-Riańo, T., Valtueña, F. J., López, J., Navarro-Pérez, M. L., Pérez-Bote, J. L. \& Ortega-Olivencia, A. 2015: Evolution of the staminode in a representative sample of Scrophularia and its role as nectar safeguard in three widespread species. Naturwissenschften 102 (5-6): 37.
Scheunert, A. \& Heubl, G. 2011: Phylogenetic relationships among New World Scrophularia L.(Scrophulariaceae): new insights inferred from DNA sequence data. Plant Systematics and Evolution 291: 69-89.

Scheunert, A. \& Heubl, G. 2014: Diversification of Scrophularia (Scrophulariaceae) in the Western Mediterranean and MacaronesiaPhylogenetic relationships, reticulate evolution and biogeographic patterns. Molecular Phylogenetics and Evolution 70: 296-313.

Scheunert, A. \& Heubl, G. 2017: Against all odds: reconstructing the evolutionary history of Scrophularia (Scrophulariaceae) despite high levels of incongruence and reticulate evolution. Organisms Diversity \& Evolution 17: 323-349.

Sharifnia, F. 2007: Notes on the distribution and taxonomy of Verbascum in Iran. Iranian Journal of Botany 31: 30-32.

Shaw, R. J. 1962: The biosystematics of Scrophularia in western North America. Aliso 5: 147-178.

Sotoodeh, A. 2015: Histoire biogéographiqueetévolutive des genres Verbascumet Artemisia en Iran à l'aide de la phylogéniemoléculaire, Université de Toulouse, Université Toulouse III-Paul Sabatier.

Stiefelhagen, H. 1910: Systematische und pflanzen geographische Studienzur Kenntnis der Gattung Scrophularia: Vorarbeitenzueiner Monographie. Botanische Jahrbücher 44: 406-496.

Tank, D. C., Beardsley, P. M., Kelchner, S. A. \& Olmstead, R. G. 2006: L. A. S. Johnson Review No. 7. Review of the systematics of Scrophulariaceaes and their current disposition. Australian Systematic Botany 19: 289-307.

The Angiosperm Phylogeny Group, Chase, M. W., Christenhusz, M. J. M., Fay, M. F., Byng, J. W., Judd, W. S., Soltis, D. E., Mabberley, D. J., Sennikov, A. N., Soltis, P. S., Stevens, P. F. 2016: An update of the Angiosperm Phylogeny Group classification for the orders and families of flowering plants: APG IV. Botanical Journal of the Linnean Society 181(1): 1-20.

Tutin, T. G., Heywood, V. H., Burgess, N. A., Moore, D. M., Valentine, D. H., Walters, S. M. \& Webbs, D. 1968: Flora Europaea vol. 3, 216-220. Cambridge University, Cambridge.

Valtuena, F. J., López, J., Álvarez, J., Rodríguez-Riaño, T. \& Ortega-Olivencia, A. 2016: Scrophularia arguta, a widespread annual plant in the Canary Islands: a single recent colonization event or a more complex phylogeographic pattern? Ecology and Evolution 6: 4258-4273.

Valtueña, F. J., Rodríguez-Riaño, T., López, J., Mayo, C. \& OrtegaOlivencia, A. 2017: Peripatric speciation in an endemic Macaronesian plant after recent divergence from a widespread relative. PLoS One12: e0178459.

Wydler, H. 1828: Essai monographique sur le genre Scrofularia. Genève: Barbezatet Delarue.

Yllmaz, G. \& Dane, F. 2012: The genus Verbascum L. in European Turkey. Botanica Serbica 36(1): 9-13. 
Table 1: Classification of Scrophularieae in genera according Oxelman et al. (2005).

Tabela 1: Klasifikacija Scrophularieae v rodove v skladu z Oxelman et al. (2005).

\begin{tabular}{|c|c|c|c|}
\hline Genus & Morphological feature & Distribution & No. of Species \\
\hline Scrophularia & $\begin{array}{l}\text { Annual, biennial or perennial to suffrutescent herbs. } \\
\text { Inflorescence thyrse with cymose. Flowers arezygomorphic. } \\
\text { Calyx five lobed, lobes equal. Corolla two lobed with a } \\
\text { rudimentary fifth stamen of various shapes at the base of the } \\
\text { upper lip. Stigma capitate to weakly bilobed. . Capsule with } \\
\text { septicidal dehiscence. }\end{array}$ & $\begin{array}{l}\text { Temperate zone of the } \\
\text { Northern Hemisphere, but } \\
\text { concentrated in Asia with } \\
\text { only a few species in Europe } \\
\text { and North America }\end{array}$ & 270 \\
\hline Verbascum & $\begin{array}{l}\text { Biennial or perennial herbs. Leaves Alternate. Inflorescence } \\
\text { thyrse or racemose. Actinomorphic flowers contain five } \\
\text { stamens. The fruit is a rounded or egg-shaped capsule. }\end{array}$ & $\begin{array}{l}\text { Northern Africa, Europe } \\
\text { and parts of Asia }\end{array}$ & 360 \\
\hline Antherothamnus & $\begin{array}{l}\text { A multi-stemmed, tall shrub. Leaves are very small, hairless, } \\
\text { and fascicled on dwarf spiky spur branchlets. Small tubular } \\
\text { flowers, strongly honey scented }\end{array}$ & Southern Africa & 1 \\
\hline Natbaliella & $\begin{array}{l}\text { Acaulescent perennial herb. Leaves rosulate, distinctly } \\
\text { petiolate. Flowers solitary, axillary. Pedicel short. Calyx } \\
\text { 5-lobed. Corolla limb 2-lipped, subactinomorphic. Stamens 4, } \\
\text { all fertile. Capsule 2-valved. }\end{array}$ & $\begin{array}{l}\text { Kyrgyzstan and western } \\
\text { China }\end{array}$ & 1 \\
\hline Oreosolen & $\begin{array}{l}\text { Acaulescent perennial herb. Leaves rosulate. Flowers in } \\
\text { fascicles and corolla tube elongate. }\end{array}$ & $\begin{array}{l}\text { Northern Himalaya and } \\
\text { Tibet }\end{array}$ & 1 \\
\hline Rhabdotosperma & $\begin{array}{l}\text { Herbs, shrubs or subshrubs. Hairy leaves alternate. } \\
\text { Inflorescence terminal, racemose. Calyx deeply 5-lobed, lobes } \\
\text { equal. Flowers somewhat actinomorphic. Stamens } 4(-5) \text {, } \\
\text { equal, exserted, the median one sometimes reduced to a } \\
\text { staminode. Capsule with septicidal dehiscence. }\end{array}$ & Tropical East Africa & 6 \\
\hline
\end{tabular}

Table 2: Intrageneric classification in Scrophularia. Numbers in brackets after section names represent corresponding species numbers.

Tabela 2: Klasifikacija znotraj rodu Scrophularia. Številke v oklepajih predstavljajo število vrst.

\begin{tabular}{lllll}
\hline Wydler (1828) & G Don (1838) & Bentham (1846) & Boissier (1879) & Stiefelhagen (1910) \\
\hline I (2) & Venilia (3) & Venilia (8) & & Tomiophyllum (67) \\
II (45) & Scorodonia (44) & Scorodonia (36) & Scorodonia (16) & Anastomosantes (76) \\
& Canina (13) & Tomiophyllum (35) & Tomiophyllum (49) \\
& & Ceramatha (11) \\
& & Pycnanthium (1) \\
& & Minima (1) & \\
\end{tabular}

Table 3: Phylogenetic studies of Scrophularieae. Nucleotide sequences include ITS and ETS from nuclear DNA; matK, ndhF, psbA-trnH, psbJ-petA, trnQ-rps 16, trnL-F, trnS-G, trnY-T from cpDNA.

Tabela 3: Filogenetske raziskave skupine Scrophularieae. Nukleotidne sekvence vključujejo ITS in ETS iz jedrne DNK; matK, ndhF, psbA-trnH, psbJ-petA, trnQ-rps 16, trnL-F, trnS-G, trnY-T iz cpDNA.

\begin{tabular}{|c|c|c|}
\hline Genus & Type of nuclear and plastid markers & Authors \\
\hline Scrophularia & $\begin{array}{l}\text { ITS, ETS, trnQ-rps16, psbA-trnH, trnS-G, } \\
\text { ndhF, trnL-F, trnQ-rps16, psbJ-petA }\end{array}$ & $\begin{array}{l}\text { Scheunert and Heubl (2011), Attar et al. (2011), Navarro-Pérezet } \\
\text { et al. (2013), Scheunert and Heubl (2014), Rodríguez-Riańoet et } \\
\text { al. (2015), Valtueńaet al. (2016), Scheunert and Heubl (2017), } \\
\text { Valtueña et al. (2017) }\end{array}$ \\
\hline Verbascum & ITS, $\operatorname{trn} S-G, p s b \mathrm{~A}-\operatorname{trn} \mathrm{H}, \operatorname{trn} Y-T, \operatorname{trn} L-F$ & Ghahremaninejad et al. (2015), Sotoodeh (2015) \\
\hline Oreosolen & ITS, $\operatorname{trnL}-F, p s b \mathrm{~A}-\operatorname{trn} \mathrm{H}, \operatorname{trn} \mathrm{Q}-r p s 16$ & Chenet al. (2017) \\
\hline
\end{tabular}

